\title{
LA CONSTRUCCIÓN VISUAL DE AMÉRICA LATINA: UNA APROXIMACIÓN DESDE LAS IMÁGENES CARTOGRÁFICAS
}

DYM, Jordana; OFFEN, Karl (eds.) Mapping Latin America: A cartographic reader. Chicago e Londres: The University of Chicago Press. 338p. ISBN 9780226618227

Verónica C. Hollman

Las imágenes documentan, exponen, dan a ver, seleccionan, ordenan y sistematizan información. Sabemos, no obstante, que éstas no son espejos de la realidad: constituyen relatos visuales sobre lo real (QUINTANA, 2003) que nos convocan, seducen, cautivan y emocionan. También, las imágenes intervienen activamente en nuestras formas de ordenar, entender $y$ posicionarnos en el mundo. Sin embargo, quienes enseñamos América Latina en cursos universitarios advertimos que las imágenes se consideran ilustraciones de las argumentaciones bajo discusión en libros claves para su estudio. El libro "Mapping Latin America", en cambio, propone un análisis de los modos de ver y mirar este espacio. Se dirige, desde su contenido y formato, a un público conformado por estudiantes de grado y pos grado de disciplinas tales como Historia, Geografía, Sociología y Antropología. Lamentablemente su circulación y utilización en la enseñanza de grado será limitada en América Latina debido al idioma de su publicación.

El título del libro inscribe las coordenadas del género de imágenes a través del cual se aspira abordar la construcción visual del espacio latinoamericano. Se trata de imágenes cartográficas que, como ha analizado ingeniosamente Denis Wood, son poderosas: nos ofrecen una

1 Doctora en Ciencias Sociales. Investigadora del Consejo Nacional de Investigaciones Científicas y Técnicas (CONICET) y profesora de la Universidad Nacional del Centro de la Provincia de Buenos Aires. vhollman@conicet.gov.ar $\checkmark$ Centro de Investigaciones Geográficas. Campus Universitario. Paraje Arroyo Seco, s/n. B7000GHG, Tandil, Argentina.

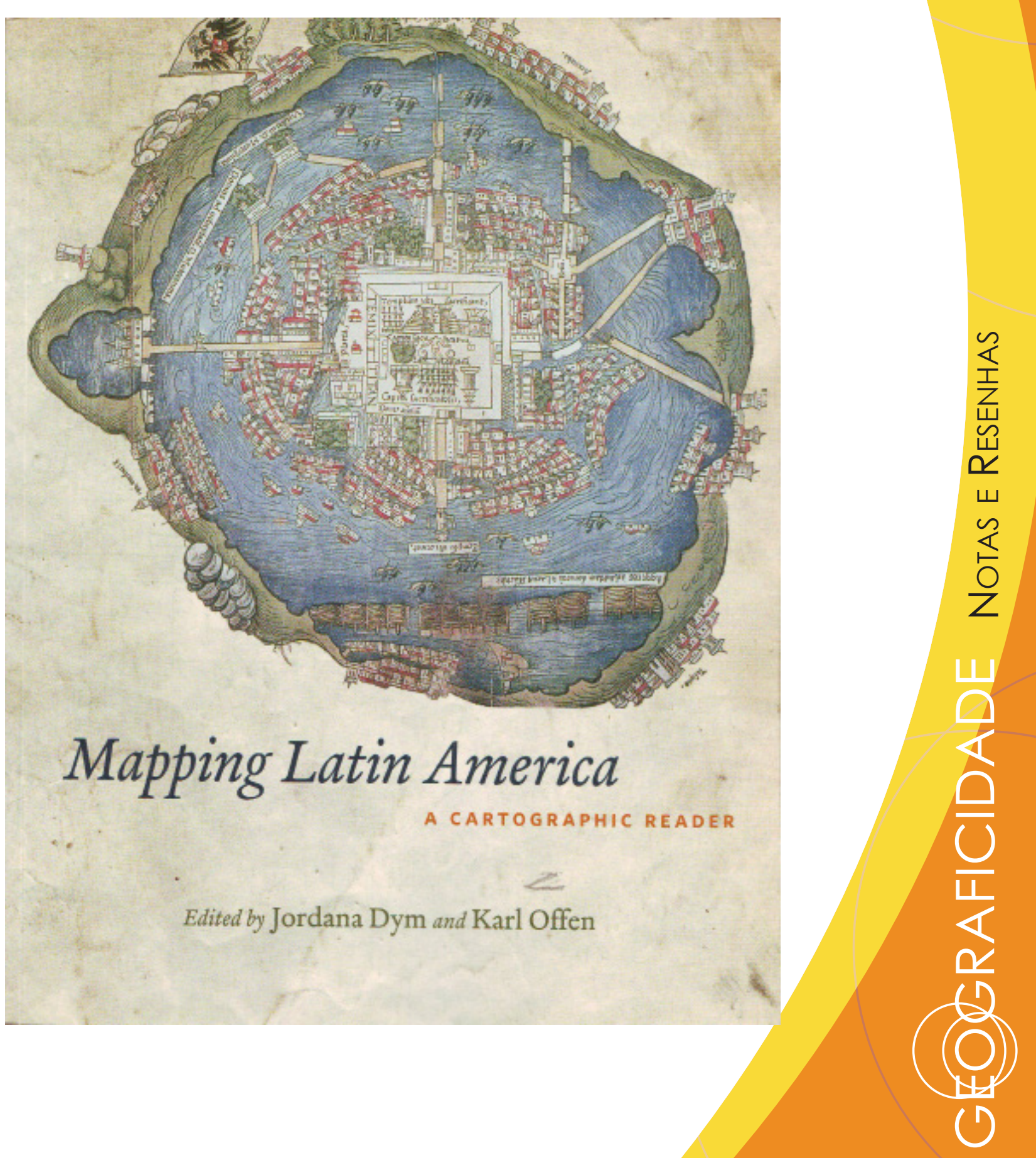


realidad que excede nuestra visión; hacen presente pasado y futuro. Las imágenes cartográficas, fundamentalmente, hacen proposiciones sobre el mundo que, a través de inclusiones y exclusiones, moldean nuestra forma de mirarlo (WOOD, 1992). "Mapping Latin America" nos invita a examinar la contribución y participación de una serie de imágenes cartográficas, como órdenes visuales, en nuestros modos de mirar y el espacio latinoamericano.

Se trata de una cuidadosa edición que presenta un conjunto de 98 mapas acompañados por ensayos breves (no más de dos o tres páginas) con interesantes y valiosas claves de interpretación aún para quienes no manejan las herramientas cartográficas básicas. El formato y el contenido de la obra, a nuestro criterio, presenta dos claras fortalezas. La primera es la posibilidad de encontrarnos con una multiplicidad de mapas que conforman el acervo cartográfico de la British Library, Archivo General de Indias, Benson Latin American Collection (University of Texas), Library of Congress (Washington) y de un vasto universo de colecciones personales, museos no especializados en cartografía, fundaciones, institutos y organismos de planificación, entre otros. La selección de los mapas toma características polifónicas: mapas producidos por indígenas, cartógrafos europeos, instituciones, comunidades, estados; mapas de distintas tradiciones cartográficas; mapas con finalidades de comunicación particulares como los mapas científicos, turísticos y propaganda. Pero también, con la decisión de tomar mapas de distintos momentos históricos y escalas geográficas diversas la recopilación cartográfica ofrece interesantes contrapuntos para entender la construcción visual de América Latina como un proceso diacrónico y multi-escalar. De allí que a la hora de entender nuestros modos de mirar Latinoamérica todos los mapas se tornan relevantes - planos de ciudades, los mapas de regiones y los mapas de territorios nacionales.
En segundo lugar, tal vez una de las mayores virtudes de esta obra, reside en renunciar al principio de que las imágenes hablan por sí mismas y proponer, como contrapartida, una metodología para el encuentro con las imágenes cartográficas ${ }^{2}$. La introducción expone con claridad la finalidad de ofrecer una guía de lectura cartográfica de las formas de representación de América Latina y su significación en distintos momentos históricos. Como señalan los compiladores: "Aprender a leer un mapa consiste en saber interrogar qué es lo que se muestra y lo que se excluye, quién produjo ese mapa, por qué y para quién" (OFFEN; DYM, 2011, p. 3). Todavía más: indagar las formas de circulación y lectura de estos mapas así como los efectos que éstos producen en sus lectores, particularmente en las formas de entender y conceptualizar el espacio latinoamericano. Todos los ensayos desarrollan algunos de los puntos de esta metodología de lectura e interpretación de las imágenes cartográficas (quién produjo el mapa, cómo, para quién y cómo fue utilizado) sin por ello borrar la especificidad de cada imagen y la creatividad de cada autor. Queda en evidencia el minucioso trabajo de los editores/organizadores del libro pues se trata de una obra colectiva (con la participación de más de 50 autores formados en distintas áreas del conocimiento).

El libro se estructura en tres secciones definidas por la dimensión temporal. Cada sección se abre con una introducción en la cual se identifican elementos claves del período y de la producción (tecnologías utilizadas, autores y propósitos) y circulación (audiencias, disponibilidad, accesibilidad) de los mapas. A su vez, los mapas y

2 En losúltimos años se han publicado maravillosos libros con compilaciones de imágenes cartográficas sugerentes que, por lo general, se presentan sin claves de lectura. Prevalecen dos supuestos: que las imágenes hablan por sí mismas y que las audiencias cuentan con una alfabetización visual para poder entenderlas e interpretarlas. Entre estas publicaciones citaremos dos libros con imágenes cartográficas bellas, creativas e innovadoras: "You are here" $y$ "The map as art", ambos de la autora Katherine Harmon (2004; 2009). 
ensayos de cada sección se ordenan temáticamente en función de las características particulares de cada período histórico.

La primera sección - el período de conquista y colonización de los territorios y comunidades (circa 1500-circa 1800) - expone el deseo y necesidad cartográfica de los conquistadores ibéricos con una orientación hacia las audiencias europeas. Asimismo, se presentan mapas producidos por indígenas y mapas en los que se combinan tradiciones cartográficas europeas con concepciones y elementos visuales propios de los indígenas. En la segunda sección - el período de independencia y formación de los estados nación (circa 1800-1900) - se analiza el deslizamiento desde la cartografía colonial a la producción de mapas nacionales o nacionalizadores en tanto proponían mostrar el cuerpo de la nación (sus territorios, poblaciones y recursos) y participar de este modo en la conformación de las identidades nacionales. Estos mapas, producidos por potencias económicas como Gran Bretaña y posteriormente por instituciones nacionales (con expediciones dirigidas por europeos), han educado los ojos "no solo de los imperialistas en las metrópolis sobre las posibilidades existentes sino también de las elites locales sobre los recursos naturales existentes en las profundidades de sus países" (OFFEN, 2011, p. 142). Algunos mapas de esta sección destacan este desplazamiento en otras escalas de representación cartográfica. Finalmente, la tercera sección - el período de reconfiguración del espacio latinoamericano por fuerzas de la industrialización, migración y globalización (siglo $X X)$ - exhibe la permanencia y visibilidad de los mapas nacionales en el imaginario geográfico pero también una diversificación de las imágenes cartográficas en relación a la inclusión de otras identidades (transnacionales, étnicas, ambientales) y en las propias prácticas de producción cartográfica.

Sin restar valor y rigor a la obra, encontramos dos dificultades que merecen ser apuntadas. El primer problema es de orden conceptual y metodológico: en las claves de lectura de lectura de algunos capítulos se pierde del análisis la especificidad de las imágenes cartográficas. Es decir, cómo participan específicamente estos mapas (y otros) en la conformación de nuestra memoria cartográfica y en nuestros imaginarios geográficos. El segundo obstáculo es de orden técnico: sabemos que la impresión de imágenes en los libros siempre impone algunas pérdidas en cuanto a su visualización (particularmente debido a los costos de impresión). Si bien el papel ilustración y los colores de publicación hacen placentero el acto de mirar cada mapa, el tamaño asignado a algunos mapas torna dificultosa la identificación de algunos detalles visuales apuntados en los ensayos. Dificultad en parte resuelta al poder visualizar algunos mapas del volumen en el website del libro³.

Finalmente quiero destacar la participación de profesores e investigadores latinoamericanos que enseñan en universidades de la región - Sylvia Ficher, Junia Ferreira Furtado, Stefanía Gallini, Fracisco Leitão, Carla Lois, Fernando PérezOyarzún, José RosasVera, entre otros. La contribución de estos investigadores latinoamericanos señala que en la región ya existen grupos de investigadores abocados a un campo de punta en la investigación social en un momento de sobreabundancia de imágenes. Pensamos que desde América Latina es posible y necesario fortalecer estos grupos conformando redes de investigación para entender más cabalmente las particularidades que han tomado en este espacio regional las relaciones entre el "ver" y el "entender"; entre el "ver" y la conformación de "memorias cartográficas"; entre el "ver" y el conjunto de experiencias y conocimientos que se recuperan y activan ante las imágenes cartográficas. Sin duda, una rica agenda de indagación que los geógrafos latinoamericanos no podemos marginar si pretendemos comprender y explicar América Latina en

3 "Ajourney through Latin American Maps from the Columbian Encouter to the present". Accesible en <http://www.press.uchicago.edu/books/MappingLatinAmerica/index. html>.. 
el mundo contemporáneo. Más todavía si deseamos que nuestros alumnos estén preparados para la aventura de mirar los mapas (y otras imágenes producidas y utilizadas desde las geografías académicas y no académicas) con tanta solvencia como la que tienen para leer críticamente un texto (GIRARDI, 2006).

\section{REFERENCIAS}

HARMON, Katherine. You are here: Personal geographies and other maps of the imagination. New York: Princeton Architectural Press, 2004. 199p.
The map as art: Contemporary artists explore cartography. New York: Princeton Architectural Press, 2009. 201p.

GIRARDI, Gisele. Aventuras da leitura de mapas. In: SEEMANN, Jörn (Org.) A aventura cartográfica: Perspectivas, pesquisas e reflexões sobre a Cartografia Humana. Fortaleza: Expressão Gráfica e Editora, 2006. p. 61-72.

QUINTANA, Ángel. Fábulas de lo visible. El cine como creador de realidades. Barcelona: 2003. 312p.

WOOD, Denis. The power of maps. New York: Guilford Press, 1992. $248 p$. 